\title{
6
}

\section{Hotspots of Present and Future Risk Within Deltas: Hazards, Exposure and Vulnerability}

\author{
Chris Hill, Frances Dunn, Anisul Haque, \\ Fiifi Amoako-Johnson, Robert J. Nicholls, \\ Pokkuluri Venkat Raju and Kwasi Appeaning Addo
}

\subsection{Introduction}

Risk, as a function of hazard, exposure, and vulnerability, is a growing characteristic of the Anthropocene concept. It is changing with evolving human assets and populations, as well as adaptation. Risk is not experienced, judged, or responded to uniformly, although often associated with levels of development and the nature of social systems (Cutter et al. 2003; Busby et al. 2014). The general tendency during the Anthropocene has been, and is likely to continue to be, low-risk tolerance in areas of high economic and investment value. Historically, this

\footnotetext{
C. Hill $(\bowtie) \cdot$ F. Dunn

GeoData Institute, Geography and Environmental Science,

University of Southampton, Southampton, UK

e-mail: cth@geodata.soton.ac.uk
}

\section{A. Haque}

Institute of Water and Flood Management, Bangladesh University of Engineering and Technology, Dhaka, Bangladesh 
has resulted in high levels of localised protective adaptation generating protected zones which encourage further development, placing additional populations and assets at risk (e.g. Welch et al. 2017). However, risk is also fluid in nature, changing over time and in response to external influences. Mapping the spatially differentiated factors of risk such as climate variability and extremes, vulnerability of populations and natural systems to climatic stressors, and adaptive capacities provides information and understanding of changing risk as an indicator for current and future adaptation needs (Chapter 9), and locations where degradation of livelihoods may trigger migration (Chapter 7).

In addition to climate change (Chapter 1), delta regions have also been widely identified as global hotspots of vulnerability and risk due to the concentration of population and engineering interventions and the nature of these unconsolidated and dynamic coastal systems (e.g. Ericson et al. 2006; Tessler et al. 2015). Within deltas there are also local scale hotspots of risk, vulnerabilities, exposure, and hazards (e.g. Chapters 2-4). These can be hazard-specific (see Fig. 6.1), but deltas also represent environments where the interplay of physical, socioeconomic, and socio-ecological systems operating over multiple spatial and temporal scales combine to produce variable levels and patterns of risk. This will inevitably continue during the Anthropocene.

F. Amoako-Johnson

University of Cape Coast, Cape Coast, Ghana

R. J. Nicholls

School of Engineering, University of Southampton, Southampton, UK

P. V. Raju

National Remote Sensing Center, Indian Space Research Organisation, Hyderabad, India

K. Appeaning Addo

Department of Marine and Fisheries Sciences, Institute for Environment and Sanitation Studies, University of Ghana, Legon-Accra, Ghana 

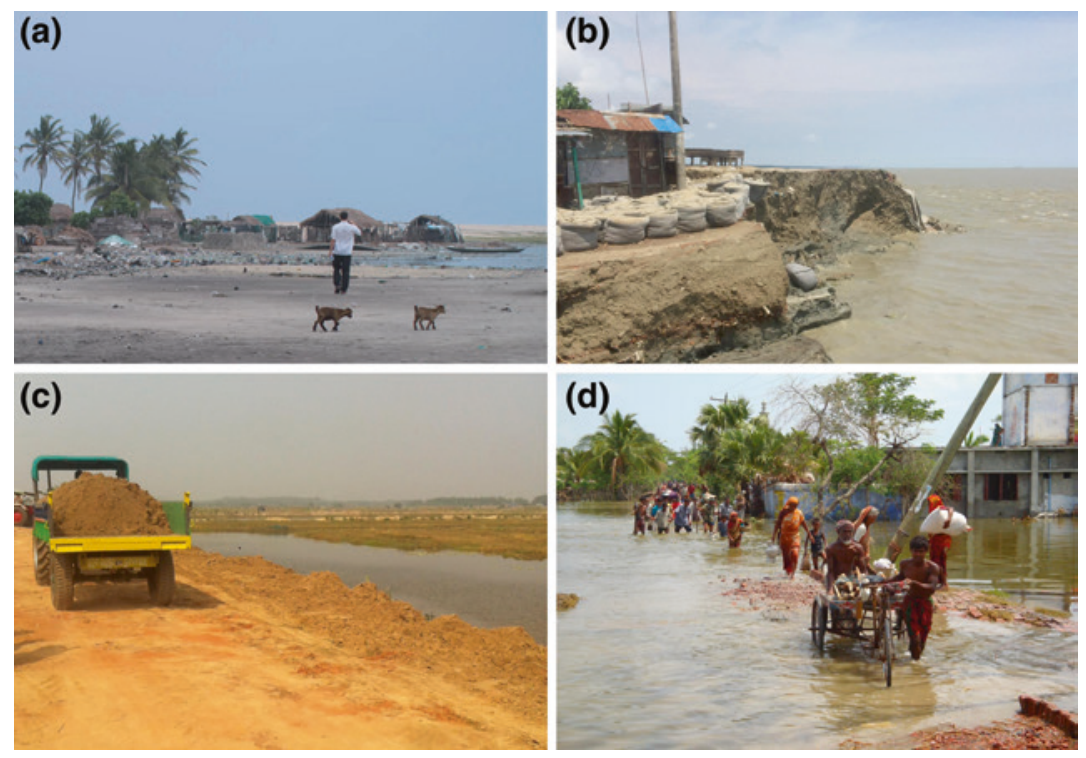

Fig. 6.1 Hazards within deltaic areas: a low-lying regions close to shoreline are exposed to regular overtopping and coastal flooding (Totope, Ghana), b coastal and river erosion processes hazards may modify locations of risk hotspots and increase populations' vulnerability (Meghna, Bangladesh, RSC), c increasing subsidence and salinisation lead to changing land use and conversion from agriculture to aquaculture e.g. saline ponds (Mahanadi), d freshwater and brackish flooding regularly affects low-lying deltaic areas and populations, however changes in the drivers of risk can cause flood-prone locations to shift or expand (Bangladesh) (Photos: a Carolin Bothe-Tews; b Ricardo Safra de Campos; c Jon Lawn; d A. K. M Saiful Islam)

This chapter therefore explores mapping present and potential future hotspots of risk with reference to three contrasting deltas (the Ganges-Brahmaputra-Meghna [GBM], Mahanadi and Volta Deltas, Chapters 2-4) under relevant scenarios (see Kebede et al. 2018). It examines risk through its components of hazards, exposure, and vulnerabilities, reflecting both changing environmental conditions and the history of interventions and adaptations. This includes consideration of the intricately interlinked feedbacks and responses to past events and 
perceived risks. It also examines the spatial and temporal nature of hotspots, particularly in relation to future variation in the frequency and magnitude of hazards associated with climate change. These hotspot risk maps can help to communicate issues clearly with stakeholders and policymakers (e.g. De Sherbinin 2014; Lewis and Lenton 2015; De Sherbinin et al. 2017) and provide a basis for future research such as the sampling strategy for the household survey analysed in Chapters 7 and 9.

\subsection{The Nature of Hazards in Deltas}

The inherent properties of deltas such as low gradient, low elevation topography, often fertile soils (Saleque et al. 2010), and proximity to rivers and seas make them attractive for concentrations of populations and anthropogenic activities. However, these properties also increase the exposure to stresses, hazards, and multiple hazards, which compromise the biophysical and socio-economic systems of deltas (Evans 2012). These stresses and hazards occur elsewhere across the world but they are accentuated in populated deltas, where multiple processes operate and interact across spatial and temporal scales (see Chapter 1, Tables 1.1 and 1.2). Beyond the impacts on socio-economic systems in deltas, all the previously discussed hazards can affect biophysical systems and therefore ecosystem processes and services (Renaud et al. 2013). Within the context of these study deltas, the definition used is a hybrid of the morphological delta (Galloway 1975) that includes a relief characterisation (the $5 \mathrm{~m}$ contour) and the administrative units that intersect with the contour (Chapter 1). Although there are many potential delta definitions, this combines the morphological with socio-economic and governance components of risk. Figure 6.2 highlights the multiple natural and anthropogenic processes, and fast and slow onset events that affect delta risks, the nature of scenarios of change, and deltaic livelihoods.

The nature of hazards is often a complex of both natural and human-induced processes: for instance, salinisation levels can affect land suitability and thereby agricultural productivity and population health through contaminated ground and surface water (Syvitski 2008). In addition to being related to relative sea-level rise (RSLR), salinisation 

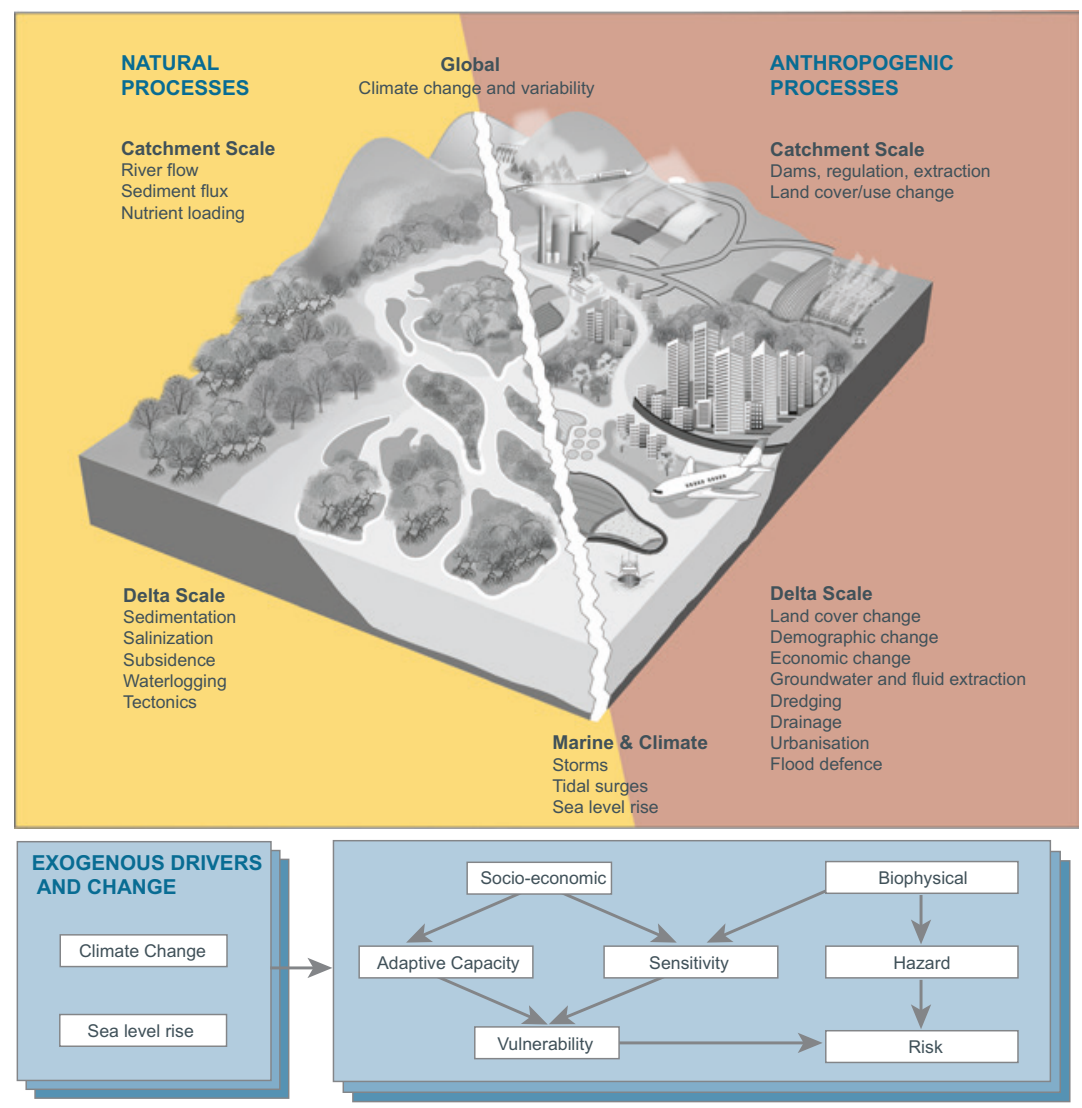

Fig. 6.2 Summary of natural atmospheric, terrestrial, marine, and anthropogenic processes in delta systems and related scenarios of risk associated with exogenous and endogenous changes

can also be caused by groundwater depletion (Erban et al. 2014), farming patterns, and agricultural practices themselves (Clarke et al. 2018). In coastal Bangladesh, salinity intrusion reflects the interplay of human and natural process, such as reductions in upstream discharge, rising sea levels and cyclonic conditions, compaction, subsidence and polderisation. Modelled scenarios of change in each of these factors show that the anthropogenic impact of intervention in upstream discharge affects the whole region, and is overlain on larger-scale exogenous factors of 
sea-level rise, and cyclone landfall and tracking. The resulting higher salinities, fluvio-tidal and tidal floods impact on cropland suitability and livelihoods (Kamal and Khan 2009). Equally, subsidence is due in part to natural processes of tectonic subsidence and natural compaction, but is accelerated by anthropogenic groundwater extraction, drainage of organic soils, and reduced sediment supply resultant from upstream dam construction and embanking which limits new sedimentation (Brown and Nicholls 2015; Darby et al. 2015). These interconnected factors are contributing to RSLR that increases the river and storm surge flood hazard and increases salinity and waterlogging (FAO 2015).

Climatic variations will continue and potentially become more severe with future climate change so the related hazards may also increase in frequency and severity (Janes et al. 2019). In the context of the three deltas considered in this book (Chapters 2-4), climate projections show regional increases in seasonally averaged temperature during the monsoon season (June-September) by the end of the twenty-first century, ranging from 3 to $5{ }^{\circ} \mathrm{C}$. They also indicate an increase in average monsoon precipitation by the end of the century, ranging from 10-40\% over central India. For Ghana, using data derived from Cordex (Janes et al. 2019) mean annual temperatures are projected to rise by $2.2{ }^{\circ} \mathrm{C}$ by 2050 s and by $3.6^{\circ} \mathrm{C}$ by 2080 s across the delta area, whilst average rainfall volumes are projected to show a modest decrease. However, the projected annual potential evapotranspiration and the number of growing days are projected to decrease, with consequent impacts on rain-fed agricultural production (Fischer and Harrij 2018). Sea-level rise is also expected, reinforced by subsidence, affecting the deltas themselves (see Chapter 5).

In addition to climatic drivers, hazards in deltas are related to other external drivers such as changes in upstream catchments (Dunn et al. 2018). Economic, industrial, and land cover change in upstream catchments can influence river water quality and quantity, modifying hazards such as river flooding, hydrological drought, erosion (sediment starvation), and river nutrient levels (Whitehead et al. 2018). Changes in river nutrients can be hazardous to fishing, aquaculture, and agriculture, as well as potential human health (Syvitski 2003; Syvitski et al. 2005). 
The characteristics of the deltas vary (see Table 6.1), but an improved understanding of risk and vulnerability needs to go beyond linear causeand-effect processes, to consider the interrelated network of natural and anthropogenic processes across scales, and feedback to the hazardproducing systems themselves.

\subsection{Identifying and Mapping Vulnerability and Risk Hotspots}

As hazards can be multiple and spatially variable, so are social vulnerabilities (Wisner et al. 2004) and hotspots occur where concentrations of hazard and vulnerability converge to create risk. Delta communities are often dependent on climate-sensitive production systems (agriculture, fish farming, natural resources_-see Chapter 8) and are subject to spatial variations in environmental stresses. Typically spatial vulnerability assessment therefore involves data integration in which geo-referenced socio-economic and biophysical data are combined with climate data to understand patterns of vulnerability.

\section{Describing Vulnerability}

Social vulnerability can be characterised by a series of factors (or domains) that are described by indicators of sensitivity (the degree to which the hazard would affect the community) and adaptive capacity (the ability of the community to cope in the short term and adjust in the longer term) to avoid the negative consequences of changes, (Amoako-Johnson and Hutton 2014; IPCC 2014). The relation can thus be expressed as:

$$
\text { Vulnerability }=\mathrm{f} \text { (Sensitivity, Adaptive Capacity) }
$$

Some indicators measure the predisposition of community vulnerability and may be directly or indirectly related to climate, but others may be largely unrelated to climate change e.g. geological hazards such as tectonics. Socio-economic factors, such as education levels or alternate livelihoods, 


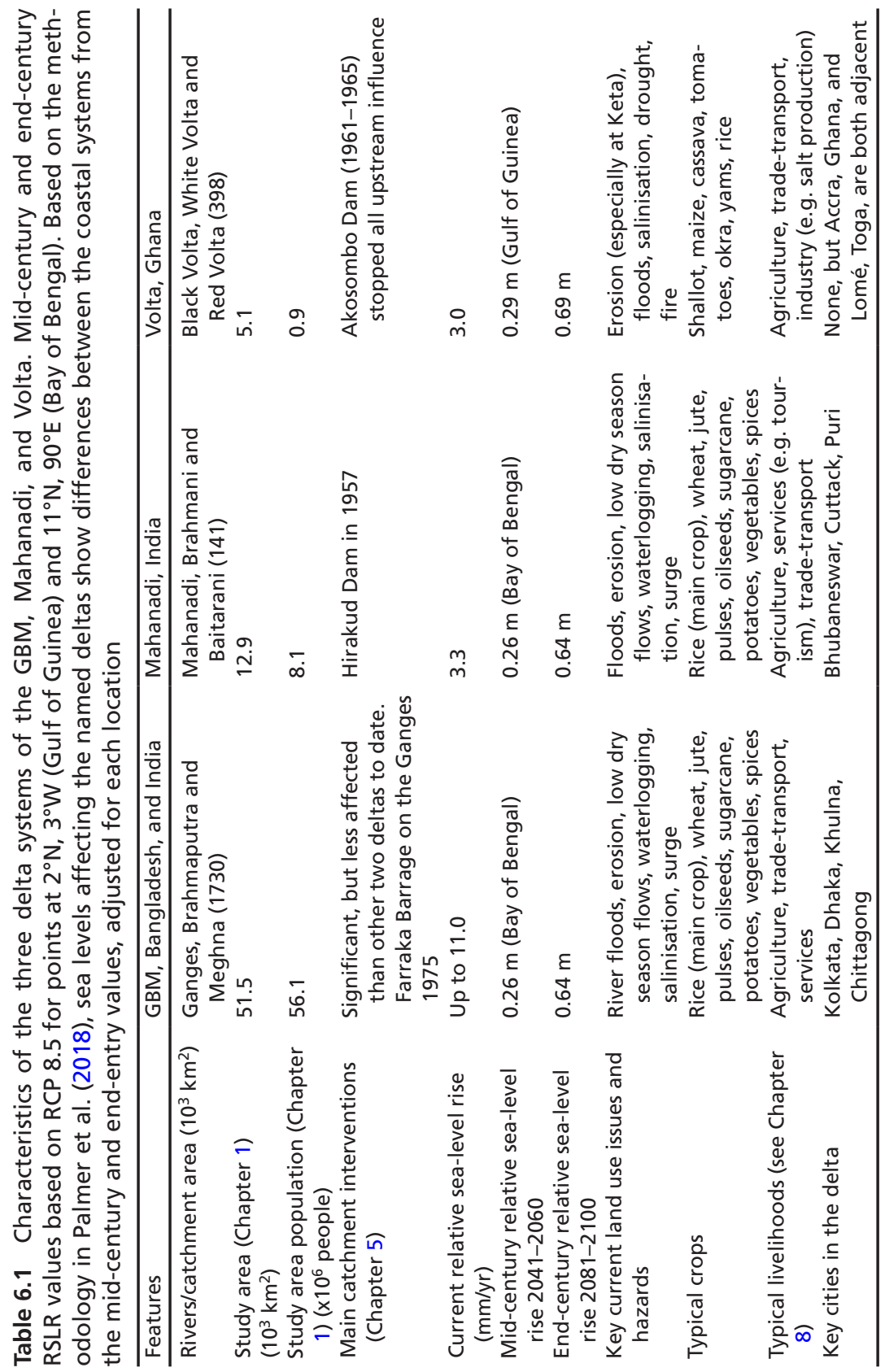


whilst independent of climate change may also be sensitive indicators of the community vulnerability and adaptability. As these are inherently hazardspecific concepts, sensitivity and adaptive capacity will change with hazard type (the factors influencing vulnerability to drought may be very different to those affected by flooding), however there is often commonality between socio-economic factors driving sensitivity such as underlying marginalisation and poverty. Critically, in terms of hotspot identification, the relationship between exposure, sensitivity and adaptive capacity vary spatially and temporally (Chen et al. 2013).

The domains and indicators of sensitivity and adaptive capacity with respect to risks are developed through stakeholder engagement at planner, land manager, community, and individual levels. The Volta Delta provides an example of the approaches used for the vulnerability mapping employing literature, stakeholder engagement, and household surveys to identify the indicators of sensitivity and adaptive capacity (Amoako-Johnson and Hutton 2014). For the Volta, ten indicators are selected to represent the sensitivity and adaptive capacity domains (Fig. 6.3) and are derived largely from enumeration level census data. The factors are inherently subjective, providing relative values of vulnerability, requiring weighting of the domain-specific relative importance; for mapping purposes, the Delphi participatory approaches were used to assign scores (Linstone and Turoff 2002). Hotspot analysis is also sensitive to the scale of the data used to identify factor variability; the highest resolution socio-economic data, based at enumeration area level, in Ghana is the 2010 census data. However, census data does not describe all the factors that may be needed to designate the domains of sensitivity and adaptive capacity. Other sources and surrogate measures, such as land cover derived from satellite information (Noor et al. 2008), may therefore be used as a measure of livelihood (i.e. dependence on agriculture and natural resources).

Methodological challenges to operating the vulnerability assessment may affect the outputs and the interpretation of the various domains of vulnerability. Data limitations, such as the lack of correspondence of data for the individual factors and multiple scales of data may affect the resolution of vulnerability analysis. Challenges include the conceptualisation of the domains, their indicators and 


\begin{tabular}{|l|l|}
\hline Livelihoods \\
\hline Least sensitive
\end{tabular}

Fig. 6.3 Geospatial variability for selected sensitivity and adaptive capacity domains and example indicators for the Volta Delta (see Amoako-Johnson et al. 2017)

measures, the degree to which data are aggregated, and the extent to which variables represented at enumeration area level are representative at the finer-scale at which hazards and stresses may be experienced by communities (Openshaw 1984). The unit of analysis issue may particularly affect communities at the coast or in riparian zones where there is exposure and susceptibility to erosional and flooding hazards in a linear zone, yet the wider sampling zone of census data include un-impacted communities. Such factors may mask significant vulnerabilities, exposure, and risk, and where vulnerability at the local level is both a predisposition to and a consequence of existing risk. This implies that the most vulnerable may have been historically exposed to risk and are likely to continue to be so in the future, in a selfreinforcing way. For example, the community on Ghana's Totope coastal barrier beach (Fig. 6.1a) are already coping and adjusting to existing hazards, are already highly exposed to storm surges and erosion hazards, and are highly vulnerable due to poverty (high sensitivity) and with limited scope to adjust livelihoods (low adaptive capacity). 
However, these 'risky locations' may be the only areas which marginalised communities can access.

Within the Volta Delta, the risk mapping described above suggests that the most sensitive areas and those with least adaptive capacity are generally focused in the north and west of the delta study area, and are generally inland. Whilst delta regions include the hazards associated with their low-lying, coastal, and riverine settings (erosion, flooding), the sensitivity and adaptive capacity of communities is related to the individual environmental stresses and may reflect other factors that marginalise communities (Amoako-Johnson et al. 2017). This implies that, despite coastal hazards and sea-level rise, communities at the coast may both benefit from shoreline protection and socio-economic opportunities that overall reduce relative vulnerability.

A similar analysis of vulnerability for the Mahanadi and GBM Deltas (Ghosh 2018; Akter et al. 2019), including the future projection of the indicators (see Sect. 6.3.3) shows both the domains and socio-economic indicators for hazard-specific adaptive capacity vary based on the relevance, stakeholder evaluation, and availability of data.

\section{Combining Vulnerability and Hazard to Map Climate Change Risk}

The Fifth Assessment Report of the IPCC (2014) conceptualises risk as an objective function of the hazard, exposure to the hazard, and the socio-economic vulnerability of both assets and communities (Eq. 6.2).

$$
\text { Risk }=\mathrm{f} \text { (Hazard, Exposure, Vulnerability) }
$$

Whilst the hazards are often conceived of as natural, they may be exacerbated by human-induced factors that accelerate or increase the magnitude of events or process or reduce through interventions and adaptations, for example, coastal defences, embankments, and polders may mitigate flood occurrence and flood levels (Mendelsohn et al. 2012; Haque and Nicholls 2018).

Using biophysical models under baseline and anticipated conditions assess these hazard-specific processes. For the Volta, Mahanadi, and 
GBM Deltas analysed here, the external forcing of hazards is simulated by upstream hydrological and downstream ocean models driven by Met Office climate model data (Janes et al. 2019). Figure 6.4 illustrates the modelled risks for river flood, salinity, erosion, and storm surge within the Bangladesh area of the GBM Delta at the upazila administrative level showing both the baseline (2011) and future modelled risks to mid-century (2050). The climate change modelling in this research used downscaled Regional Climate Models RCMs Cordex Africa (0.44 degrees) and a new PRECIS South Asia downscaled data to (0.22 degrees, c. $25 \mathrm{~km}$ ) from three selected Global Climate Models (GCMs) and based on a 'worst case' scenario using Representative Concentration Pathway (RCP) 8.5 for greenhouse gas concentrations and temperature changes developed under the Intergovernmental Panel on Climate Change Fifth Assessment Report (Janes et al. 2019). Hazard-specific risks for the future (mid-century) have been assessed by using simulations from biophysical models for storm surge, river flood, coastal erosion, riverbank erosion, and salinisation using the Delft 3D model suite, and the integrated catchment models (INCA) (Jin et al. 2018) provides the upstream boundary conditions (fluxes of freshwater water and nutrients) to secondary impact models. The sea-level rise scenarios are taken from Table 6.1.

Figure $6.4 \mathrm{~b}, \mathrm{~d}, \mathrm{f}, \mathrm{h}$ illustrate the changing nature of the risk in Bangladesh for four principle hazards: river floods, salinity, erosion, and coastal storm surges. It is important to note that the changing risk is the combination of the changes in the hazards, vulnerability, and exposure components. Projections have been used for indicators where data are available or are projected e.g. female to male ratio, poverty rate. The current (baseline) flood risk in these regions of Bangladesh is mainly dominated by flood hazard; flood risk in the mid-century period increases in the northern districts of Jessore and Narail which is mainly due to increased exposure in these regions (Fig. 6.4e). The storm surge risk impact in the mid-century comes only through sealevel rise, not any change in cyclone strength which is not included. In the central region, decreased storm surge risk in the mid-century (Fig. 6.4f) is interpreted as not being due to decreased surge hazard but mainly due to decreased poverty in the region that ultimately reduces 
the vulnerability. Similarly, salinity risk in this region has a varied relationship to salinity hazard. Results in mid-century (right image of Fig. 6.4g) shows some decreased salinity risk in the western and central region, which is interpreted as mainly due to decreased poverty that reduces future vulnerability in the region. As described, erosion in the region is confined along the Lower Meghna and along the Tetilia system. Reduced socio-economic vulnerability has little effect on reducing future erosion risk in the region, which is evident from the risk zonation in base condition and in mid-century (Fig. 6.4h).

Combining individual risks reveals a different aspect of hotspots; as such it does not represent any specific event and may therefore have a reduced sectoral policy relevance. However, multi-risk analysis represents risk zoning comprising weighted impacts of the hazard-specific risks to reflect the aggregation of environmental stress. Distribution of multi-risk for the Bangladesh GBM Delta in baseline and in midcentury conditions (see Fig. 6.5) shows an increased total risk impact in the eastern region which is mainly due to the sustained very high storm surge risk in this region (see Fig. 6.4g). On the other hand, increased risk impact during mid-century in the western zone is due to increased risks of flood, storm surge, and salinity in this region.

Changes in agro-meteorological conditions (rainfall, temperature, evapotranspiration) also drive land use and productivity changes; National Agro Ecological Zoning (NAEZ) models simulate the agricultural yield and potential production for selected crops under changing climate and socio-economic inputs (Fischer et al. 2012; Clarke et al. 2018; Fischer and Harrij 2018). NAEZ modelling has assessed the area of suitable land relative to a baseline (1981-2010) and for two future periods (2050s and 2080s) based on the climate model inputs to provide production estimates for periods, both with and without $\mathrm{CO}_{2}$ fertilisation (increased levels of photosynthesis resulting from increased atmospheric carbon dioxide). The baseline is for the period 1981-2010, for future climate in 2050s (ensemble mean of simulations with three climate models for the period 2041-2070) and for the 2080s (for the period 2070-2099). Taking the example of the SE Asia domain, Table 6.2 illustrates the changes in suitable area and potential production of selected crops in India (Mahanadi and GBM) and Bangladesh GBM 

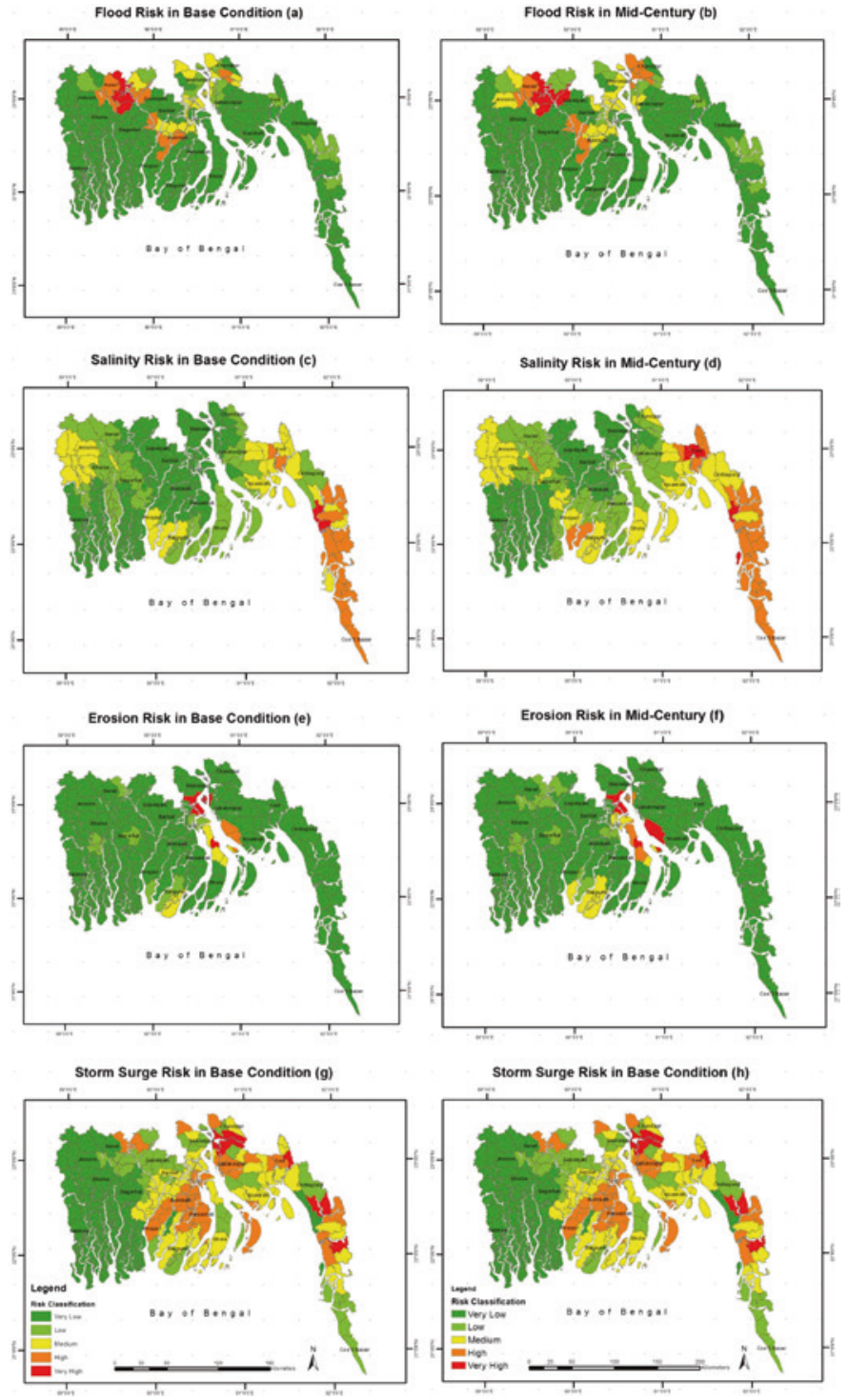

Fig. 6.4 Assessment of hazard-specific risk for the GBM Delta in Bangladesh for baseline and mid-century conditions: $\mathbf{a}, \mathbf{b}$ river flood risk, c, $\mathbf{d}$ salinity, e, $\mathbf{f}$ erosion, and $\mathbf{g}$, $\mathbf{h}$ storm surge risk. Baseline assessment is to 2001 and mid-century to 2050 

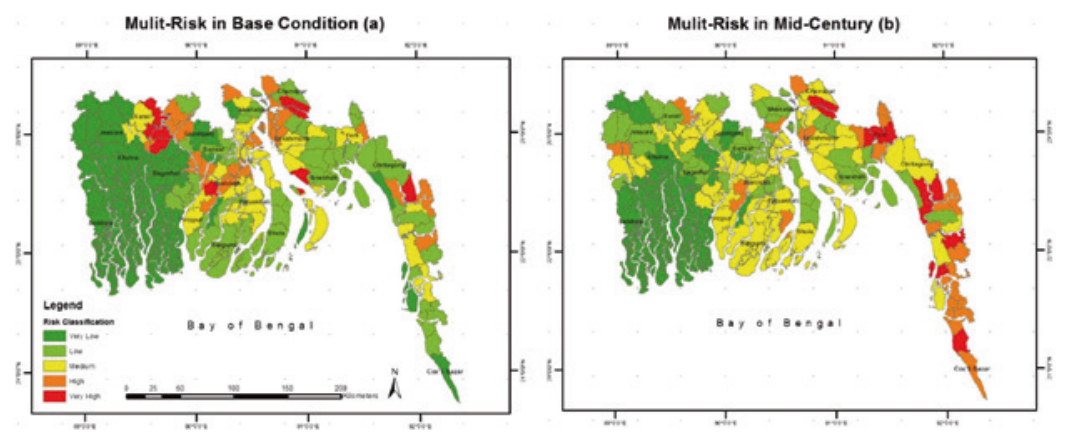

Fig. 6.5 Multi-risk assessment for the Bangladesh area of the GBM Delta (in base condition a and in a mid-century b)

Delta areas of interest. This illustrates the progressive changes in land suitability for crops, and the frequent intensification of production losses. Whilst areas become unsustainable in the later period (2080s) for some crops, such as barley, for the production of coconut, an important cash crop, there are substantial losses without $\mathrm{CO}_{2}$ fertilisation and in contrast gains with $\mathrm{CO}_{2}$ fertilisation with consequent divergent impacts on cropping and incomes.

Similarly, the climate data drives marine hydrodynamics and biogeochemistry models (POLCOMS-ERSEM [Kay et al. 2018]) delivering biophysical projections (sea levels and temperatures). Ecosystem and fisheries productivity and potential catch projections are made using the Size Spectrum-Dynamic Bioclimatic Envelope Model (SS-DBEM) (Cheung et al. 2009; Hossain et al. 2018; Lauria et al. 2018) for the coastal offshore zones of the Bay of Bengal and Gulf of Guinea illustrate the potential impacts of climate change and management scenarios on resources and production systems; for coastal fisheries and rural agricultural production potentials and relevance to livelihood choices (Bernier et al. 2016).

\section{Temporal Changes in Vulnerability}

As illustrated in the previous section with climate change and environmental hazards (and see Mendelsohn et al. 2012), hotspots of risk are not static. Changes to assets and socio-ecological systems, production 


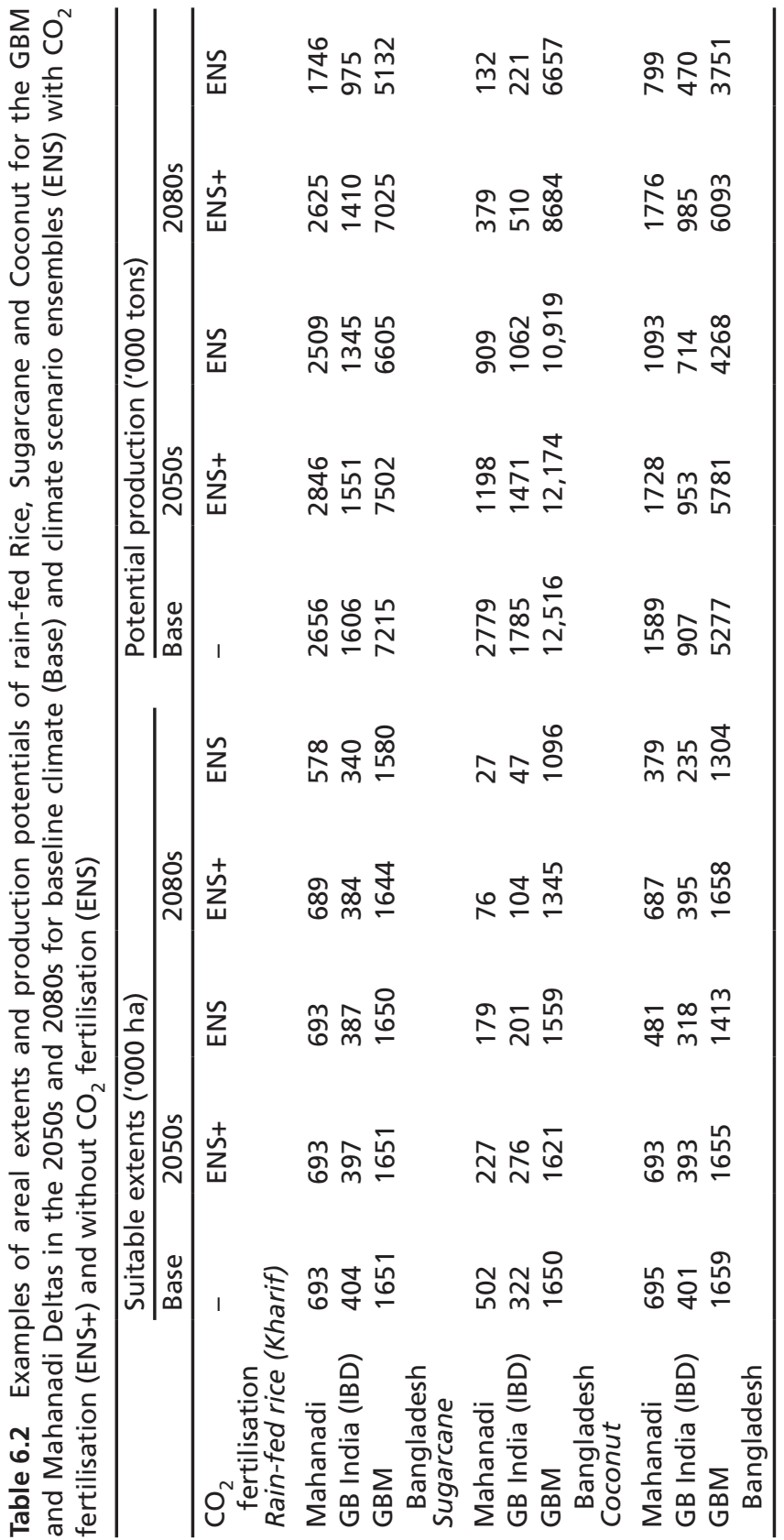


systems, population, land use change, and economic development all change over time and scale and may be even more determinants of changes in risk in the short term.

Historic analysis for the combined GBM using census data from 2001 to 2011 illustrates such changes. Figure 6.5b shows several sub-districts are socio-economically vulnerable and sub-districts like Barrackpur-I \& II, Rajarhat, Daulatpur, and Raozan are socio-economically least vulnerable in both time periods. A social vulnerability gradient exists across the delta coast, where socially marginalised and vulnerable communities are found on the delta margin in both India and Bangladesh (Fig. 6.6b, see also Chapter 2). Five principal components largely determine social vulnerability in GBM Delta: (i) rural population, (ii) house ownership, (iii) agriculture dependency, (iv) lack of sanitation, and (v) existence of mud houses. Several coastal sub-districts like Koyra, Manpura, Shyamnagar, Basanti, and Morrelganj have maximum social vulnerability and have the potential to be adversely affected by environmental change, where focussed adaptation measures are immediately needed. Amongst the most vulnerable districts, Bhola, Pirojpur, Bagerhat, Shariatpur, Chandpur, and Lakshmipur show increasing trend in vulnerability ranking between 2001-2011 whilst

(a)

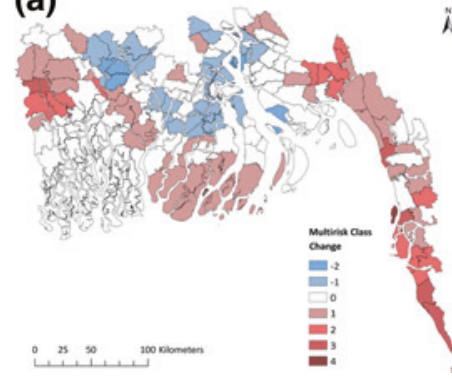

(b)

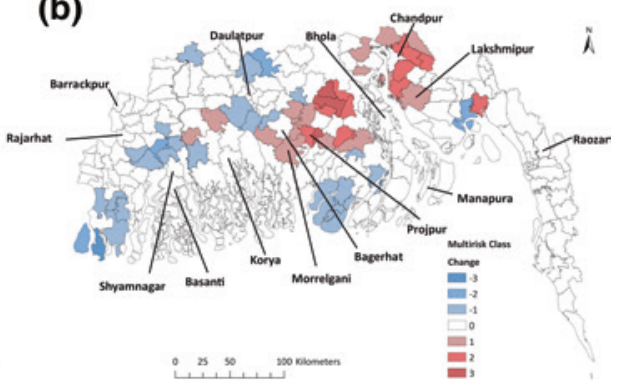

Fig. 6.6 Historical change in the location of hotspots between 2001 and 2011 based on census analysis: a change in multi-risk for the period in Bangladesh, b change in vulnerability across the combined GBM (India and Bangladesh). The figures are a relative risk rather than absolute values. Multi-risk change classes -ve scores (blue) are reducing risk/vulnerability change and +ve scores (red) indicate increased risk/vulnerability change classes 
most of the other district show positive change or no change, suggesting an absence of focussed vulnerability reduction measures other than normal developmental activities.

Hypothetically, risk may be seen typically as increasing due to climate change impacts, but may be offset by adaptations and coastal/ flood defences with consequent improved livelihoods and development. However, the unitary benefits gained by protection and reduced risk may collectively be lost as higher populations or assets are attracted or developed within risk zones which may increase the overall potential losses. Thus, future risk assessment requires evaluation of change scenarios from both biophysical and socio-economic contexts (Kebede et al. 2018).

\subsection{Conclusion}

As the Anthropocene progresses hazards are anticipated to evolve, associated with changes in long-term climate variability (such as average precipitation, temperature, and seasonal patterns), increasing number and intensity of extreme events (e.g. tropical storms, droughts), and sealevel rise/subsidence. Risks will also evolve due to socio-environmental, livelihood, assets, and infrastructure changes, reflecting the influences of economic development (e.g. urbanisation, access, irrigation), changes to production (e.g. agricultural, fisheries), changing community and household livelihoods, as well as the adaptation response to hazards and exposure. As a consequence, hotspot patterns will change over time.

Delta-level hotspot analysis offers a basis for identifying and targeting actions to support community adaptation to climate change and other stresses (Chapter 9). This is more than just mapping hazardous events. The combined geospatial analyses help to establish locations and explanations for the highest vulnerabilities and exposure and underpin effective, local actions to increase resilience. A delta-wide assessment of the multi-hazard nature and multiple indicators of vulnerability emphasises that changing risk is due to more than the obvious hazard drivers, and changes in sensitivity and adaptive capacity may counterbalance increased hazards. Within the Anthropocene there is an increasing link 
between the natural and man-made hazards, introducing new risks. A key conclusion based mainly on the Volta Delta analyses is the importance of non-marine climate hazards, such as drought, and the importance of non-climate vulnerabilities such as poor access to livelihood resources and development opportunities. In the Volta Delta, many risk hotspots are remote from the coastal fringe and its hazards, reflecting a wider pressure on livelihoods from long-term drought. The Volta results also suggest that access to livelihood resources, e.g. roads, is a significant influence on the vulnerability of communities. Hence, increasing access may be part of a comprehensive strategy for reducing risk. This shows that the components of hotspot risk analysis offer insights based on local community and stakeholder-defined sensitive indicators. These components are established within the context of the delta-specific environment and livelihoods systems. However, it should be noted that these relationships are associative and may not be causal.

Understanding the links and relationships between the components of vulnerability and drivers of change can have policy implications; helping to inform national and sub-national policy formulation to address the impacts of environmental changes, and the social processes and drivers that determine inequalities. Many deltas are subject to climate change policies, development strategies and delta management plans (e.g. NAPCC 2008; MoEF 2009; BDP 2100 2018). These indicate where an improved knowledge of community vulnerabilities and current adaptations can help formulate policies and support mechanisms that address the most vulnerable. As such they may also focus the opportunities and locations for adaptation, such as changing agricultural land use, crop types, and agricultural policy. Identifying potential future hotspots and potential change in hotspots can help decision-makers address the determinants of poverty and inequality and also support sustainable growth and development.

Ultimately, mapping hotspots of risk, vulnerability, and the constituents of vulnerability indicate the unequal distribution of the risk. This highlights that during the Anthropocene a wider appreciation of the nature of risk hotspots is essential in order to inform management and make the necessary adaptation choices. The trade-offs that this will entail are discussed further in Chapter 10. 


\section{References}

Akter, R., Sakib, M., Najmus Sakib, M., Asik, T. Z., Maruf, M. N., Haque, A., et al. (2019). Comparative analysis of salinity intrusion in Bangladesh coast due to impacts of reduced upstream discharge, sea level rise and cyclonic condition. Science of the Total Environment (in press).

Amoako-Johnson, F., \& Hutton, C. W. (2014). Dependence on agriculture and ecosystem services for livelihood in Northeast India and Bhutan: Vulnerability to climate change in the Tropical River Basins of the Upper Brahmaputra. Climatic Change, 127(1), 107-121. https://doi.org/10.1007/ s10584-012-0573-7.

Amoako-Johnson, F., Quashigah, P. N. J., Hornby, D., Hill, C., Abu, M., Appeaning Addo, K., et al. (2017, July 2-5). Uncovering climate-stressed and socially-vulnerable hotspots in the Volta Delta of Ghana: A geospatial analysis. Deltas, Vulnerability and Climate Change: Migration and Adaptation (DECCMA) Project Presentation. Accra, Ghana: DECCMA Consortium.

BDP 2100. (2018). Bangladesh Delta Plan 2100. Volumes 1-Strategy and 2Investment Plan. General Economics Division (GED), Bangladesh Planning Commission, Government of the People's Republic of Bangladesh, Dhaka, Bangladesh. https://www.bangladeshdeltaplan2100.org/. Last accessed 8 October 2018.

Bernier, Q., Sultana, P., Bell, A. R., \& Ringler, C. (2016). Water management and livelihood choices in southwestern Bangladesh. Journal of Rural Studies, 45, 134-145. https://doi.org/10.1016/j.jrurstud.2015.12.017.

Brown, S., \& Nicholls, R. (2015). Subsidence and human influences in mega deltas: the case of the Ganges-Brahmaputra-Meghna. Science of the Total Environment, 527, 362-374. https://doi.org/10.1016/j. scitotenv.2015.04.124.

Busby, J. W., Cook, K. H., Vizy, E. K., Smith, T. G., \& Bekalo, M. (2014). Identifying hot spots of security vulnerability associated with climate change in Africa, 124(4), 717-731. https://doi.org/10.1007/s10584-014-1142-z.

Chen, W., Cutter, S. L., Emrich, C. T., \& Shi, P. (2013). Measuring social vulnerability to natural hazards in the Yangtze River Delta region, China. International Journal of Disaster Risk Science, 4(4), 169-181. https://doi. org/10.1007/s13753-013-0018-6.

Cheung, W. W. L., Lam, V. W. Y., Sarmiento, J. L., Kearney, K., Watson, R., \& Pauly, D. (2009). Projecting global marine biodiversity impacts under climate change scenarios. Fish and Fisheries, 10(3), 235-251. https://doi. org/10.1111/j.1467-2979.2008.00315.x. 
Clarke, D., Lázár, A. N., Saleh, A. F. M., \& Jahiruddin, M. (2018). Prospects for agriculture under climate change and soil salinisation. In R. J. Nicholls, C. W. Hutton, W. N. Adger, S. E. Hanson, M. M. Rahman \& M. Salehin (Eds.), Ecosystem services for well-being in deltas: Integrated assessment for policy analysis. Cham, Switzerland: Springer. http://dx.doi. org/10.1007/978-3-319-71093-8_24.

Cutter, S. L., Boruff, B. J., \& Shirley, W. L. (2003). Social vulnerability to environmental hazards. Social Science Quarterly, 84(2), 242-261. https:// doi.org/10.1111/1540-6237.8402002.

Darby, S. E., Dunn, F. E., Nicholls, R. J., Rahman, M., \& Riddy, L. (2015). A first look at the influence of anthropogenic climate change on the future delivery of fluvial sediment to the Ganges-Brahmaputra-Meghna delta. Environmental Science: Processes \& Impacts, 17(9), 1587-1600. https://doi. org/10.1039/C5EM00252D.

De Sherbinin, A. (2014). Climate change hotspots mapping: What have we learned? Climatic Change, 123(1), 23-37. https://doi.org/10.1007/ s10584-013-0900-7.

De Sherbinin, A., Apotsos, A., \& Chevrier, J. (2017). Mapping the future: Policy applications of climate vulnerability mapping in West Africa. The Geographical Journal, 183(4), 414-425. https:/doi.org/10.1111/ geoj. 12226.

Dunn, F. E., Nicholls, R. J., Darby, S. E., Cohen, S., Zarfl, C., \& Fekete, B. M. (2018). Projections of historical and 21st century fluvial sediment delivery to the Ganges-Brahmaputra-Meghna, Mahanadi, and Volta Deltas. Science of the Total Environment, 642, 105-116. https://doi.org/10.1016/j. scitotenv.2018.06.006.

Erban, L. E., Gorelick, S. M., \& Zebker, H. A. (2014). Groundwater extraction, land subsidence, and sea-level rise in the Mekong Delta, Vietnam. Environmental Research Letters, 9(8), 084010.

Ericson, J. P., Vörösmarty, C. J., Dingman, S. L., Ward, L. G., \& Meybeck, M. (2006). Effective sea-level rise and deltas: Causes of change and human dimension implications. Global and Planetary Change, 50(1-2), 63-82. https://doi.org/10.1016/j.gloplacha.2005.07.004.

Evans, G. (2012). Deltas: The fertile dustbins of the continents. Proceedings of the Geologists' Association, 123(3), 397-418. https://doi.org/10.1016/j. pgeola.2011.11.001.

FAO. (2015). Mapping exercise on water-logging in south west of Bangladesh. Rome, Italy: Food and Agriculture Organization (FAO). https://fscluster. org/bangladesh/documents. Last accessed 28 November 2018. 
Fischer, G., \& Harrij, T. V. (2018). Climate change impacts on suitability of main crops in the DECCMA study areas in Ghana and in South Asia. Deltas, Vulnerability and Climate Change: Migration and Adaptation (DECCMA) Project Report. Southampton, UK: DECCMA Consortium.

Fischer, G., Nachtergaele, F. O., Prieler, S., Teixeira, E., Toth, G., van Velthuizen, H., et al. (2012). Global Agro-Ecological Zones (GAEZ v3.0) Model documentation. Laxenburg, Austria: IIASA; Rome, Italy: FAO.

Galloway, W. E. (1975). Process framework for describing the morphologic and stratigraphic evolution of deltaic depositional systems. In M. L. Broussard (Ed.), Deltas, models for exploration (pp. 87-98). Houston, TX: Houston Geological Society.

Ghosh, S. (2018). A cross-border coal power plant could put Sundarbans at risk. The Wire.

Haque, A., \& Nicholls, R. J. (2018). Floods and the Ganges-BrahmaputraMeghna Delta. In R. J. Nicholls, C. W. Hutton, W. N. Adger, S. E. Hanson, M. M. Rahman, \& M. Salehin (Eds.), Ecosystem services for well-being in deltas: Integrated assessment for policy analysis (pp. 147-159). Cham, Switzerland: Springer. http://dx.doi.org/10.1007/978-3-319-71093-8_8.

Hossain, M. A. R., Ahmed, M., Ojea, E., \& Fernandes, J. A. (2018). Impacts and responses to environmental change in coastal livelihoods of south-west Bangladesh. Science of the Total Environment, 637-638, 954-970. https:// doi.org/10.1016/j.scitotenv.2018.04.328.

IPCC. (2014). Climate change 2014: Impacts, adaptation, and vulnerability. Part A: Global and sectoral aspects. In C. B. Field, V. R. Barros, D. J. Dokken, K. J. Mach, M. D. Mastrandrea, T. E. Bilir, M. Chatterjee, K. L. Ebi, Y. O. Estrada, R. C. Genova, B. Girma, E. S. Kissel, A. N. Levy, S. MacCracken, P. R. Mastrandrea, \& L. L. White (Eds.), Contribution of working group II to the fifth assessment report of the intergovernmental panel on climate change (p. 1132). Cambridge, UK and New York, NY: Cambridge University Press. http://www.ipcc.ch/report/ar5/wg2/. Last accessed 8 October 2018.

Janes, T., McGrath, F., Macadam, I., \& Jones, R. (2019). High-resolution climate projections for South Asia to inform climate impacts and adaptation studies in the Ganges-Brahmaputra-Meghna and Mahanadi Deltas. Science of the Total Environment, 650, 1499-1520. https://doi.org/10.1016/j. scitotenv.2018.08.376.

Jin, L., Whitehead, P. G., Appeaning Addo, K., Amisigo, B., Macadam, I., Janes, T., et al. (2018). Modeling future flows of the Volta River system: Impacts of climate change and socio-economic changes. Science of The Total Environment, 637-638, 1069-1080. 
Kamal, A. H. M., \& Khan, M. A. A. (2009). Coastal and estuarine resources of Bangladesh: Management and conservation issues. Maejo International Journal of Science and Technology, 3(2), 313-342.

Kay, S., Caesar, J., \& Janes, T. (2018). Marine dynamics and productivity in the Bay of Bengal. In R. J. Nicholls, C. W. Hutton, W. N. Adger, S. E. Hanson, M. M. Rahman, \& M. Salehin (Eds.), Ecosystem services for well-being in deltas: Integrated assessment for policy analysis (pp. 263-275). Cham, Switzerland: Springer. http://dx.doi. org/10.1007/978-3-319-71093-8_14.

Kebede, A. S., Nicholls, R. J., Allan, A., Arto, I., Cazcarro, I., Fernandes, J. A., et al. (2018). Applying the global RCP-SSP-SPA scenario framework at sub-national scale: A multi-scale and participatory scenario approach. Science of the Total Environment, 635, 659-672. http://dx.doi. org/10.1016/j.scitotenv.2018.03.368.

Lauria, V., Das, I., Hazra, S., Cazcarro, I., Arto, I., Kay, S., et al. (2018). Importance of fisheries for food security across three climate change vulnerable deltas. Science of the Total Environment, 640-641, 1566-1577. http:// dx.doi.org/10.1016/j.scitotenv.2018.06.011.

Lewis, K. H., \& Lenton, T. M. (2015). Knowledge problems in climate change and security research. Wiley Interdisciplinary Reviews: Climate Change, 6(4), 383-399. https://doi.org/10.1002/wcc.346.

Linstone, H. A., \& Turoff, M. (Eds.). (2002). The Delphi method: Techniques and applications, Digital edition. Boston, MA: Addison-Wesley. https:// web.njit.edu/ - turoff/pubs/delphibook/index.html. Last accessed 8 October 2018.

Mendelsohn, R., Emanuel, K., Chonabayashi, S., \& Bakkensen, L. (2012). The impact of climate change on global tropical cyclone damage. Nature Climate Change, 2, 205. http://dx.doi.org/10.1038/nclimate1357.

MoEF. (2009). Bangladesh Climate Change Strategy and Action Plan 2009. Government of the People's Republic of Bangladesh, Dhaka, Bangladesh. Ministry of Environment and Forestry (MoEF). https://www.iucn.org/ content/bangladesh-climate-change-strategy-and-action-plan-2009. Last accessed 8 October 2018.

NAPCC. (2008). Prime Minister Council on Climate Change Report. Ministry of Environment, Forest and Climate Change, Government of India, New Delhi, India. National Action Plan on Climate Change (NAPCC).

Noor, A. M., Alegana, V. A., Gething, P. W., Tatem, A. J., \& Snow, R. W. (2008). Using remotely sensed night-time light as a proxy for poverty in Africa. Population Health Metrics, 6(1), 5. http://dx.doi.org/10.1186/1478-7954-6-5. 
Openshaw, S. (1984). The modifiable areal unit problem. Concepts and Techniques in Modern Geography. Norwich, UK: Geo Books.

Palmer, M. D., Harris, G. R., \& Gregory, J. M. (2018). Extending CMIP5 projections of global mean temperature change and sea level rise due to thermal expansion using a physically-based emulator. Environmental Research Letters, 13(8), 084003. http://dx.doi.org/10.1088/1748-9326/aad2e4.

Renaud, F. G., Syvitski, J. P. M., Sebesvari, Z., Werners, S. E., Kremer, H., Kuenzer, C., et al. (2013). Tipping from the Holocene to the Anthropocene: How threatened are major world deltas? Current Opinion in Environmental Sustainability, 5(6), 644-654. http://dx.doi.org/10.1016/j. cosust.2013.11.007.

Saleque, M. A., Uddin, M. K., Salam, M. A., Ismail, A. M., \& Haefele, S. M. (2010). Soil characteristics of saline and non-saline deltas of Bangladesh. In C. T. Hoanh, B. W. Szuster, K. Suan-Pheng, A. M. Ismail, \& A. D. Noble (Eds.), Tropical delta and coastal zones: Food production, communities and environment at the land-water interface. Wallingford, UK: CAB International.

Syvitski, J. P. M. (2003). Supply and flux of sediment along hydrological pathways: Research for the 21st century. Global and Planetary Change, 39(1), 1-11. https://doi.org/10.1016/S0921-8181(03)00008-0.

Syvitski, J. P. M. (2008). Deltas at risk. Sustainability Science, 3(1), 23-32. https://doi.org/10.1007/s11625-008-0043-3.

Syvitski, J. P. M., Vörösmarty, C. J., Kettner, A. J., \& Green, P. (2005). Impact of humans on the flux of terrestrial sediment to the global coastal ocean. Science, 308(5720), 376. http://dx.doi.org/10.1126/science.1109454.

Tessler, Z., Vörösmarty, C. J., Grossberg, M., Gladkova, I., Aizenman, H., Syvitski, J., et al. (2015). Profiling risk and sustainability in coastal deltas of the world. Science, 349(6248), 638-643. http://dx.doi.org/10.1126/science. aab3574.

Welch, A. C., Nicholls, R. J., \& Lázár, A. N. (2017). Evolving deltas: Co-evolution with engineered interventions. Elementa Science of the Anthropocene, 5, 49. http://dx.doi.org/10.1525/elementa.128.

Whitehead, P. G., Jin, L., Macadam, I., Janes, T., Sarkar, S., Rodda, H. J. E., et al. (2018). Modelling impacts of climate change and socio-economic change on the Ganga, Brahmaputra, Meghna, Hooghly and Mahanadi river systems in India and Bangladesh. Science of the Total Environment, 636, 1362-1372 http://dx.doi.org/10.1016/j.scitotenv.2018.04.362.

Wisner, B., Blaikie, P., Cannon, T., \& Davis, I. (2004). At risk: Natural hazards, people's vulnerability and disasters (2nd ed.). Abingdon, UK: Routledge. 
Open Access This chapter is licensed under the terms of the Creative Commons Attribution 4.0 International License (http://creativecommons.org/ licenses/by/4.0/http://creativecommons.org/licenses/by/4.0/), which permits use, sharing, adaptation, distribution and reproduction in any medium or format, as long as you give appropriate credit to the original author(s) and the source, provide a link to the Creative Commons license and indicate if changes were made.

The images or other third party material in this chapter are included in the chapter's Creative Commons license, unless indicated otherwise in a credit line to the material. If material is not included in the chapter's Creative Commons license and your intended use is not permitted by statutory regulation or exceeds the permitted use, you will need to obtain permission directly from the copyright holder.

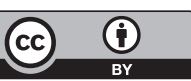

